\title{
Analysis of Student Needs on the Development of Google Classroom-Based Digital Teaching Materials in Physics Subjects for Class VIII of Kalam Kudus Christian Middle School, Surakarta
}

\author{
Felixtian Teknowijoyo, Sunardi, Gunarhadi
}

Master in Educational Technology, Universitas Sebelas, Maret Jl. IrSutami No. 36A, Surakarta, Central Java, Indonesia

\begin{abstract}
The research objective was to analyze student needs for the development of digital teaching materials based on google classroom in physics subjects at Kalam Kudus Christian Middle School, Surakarta. The research method used is descriptive analysis, namely by analyzing the students' needs for teaching materials based on google classroom using questionnaires and interviews. Google classroombased teaching materials are a solution to problems that occur in education, namely helping students learn according to their style, collaborating with others online, and becoming beings who have critical thinking in solving problems. The results showed that almost all students wanted classroom-based digital teaching materials in learning activities, this can be seen from the acquisition of a questionnaire, which is $96.5 \%$ of students answered agree to apply classroom-based digital teaching materials. The development of digital teaching materials based on google classroom is the basic foundation that everyone will build new forms of knowledge by combining the information that comes, then with what has been stored in memory, and previous learning outcomes.
\end{abstract}

Keywords—Digital Teaching Materials, Google, Classroom.

\section{INTRODUCTION}

Technology has changed and developed rapidly in the way of teaching in the classroom. Students today are known as the millennial generation and digital natives who seem to assimilate technology in every aspect of their lives. However, even so, they are digital immigrants with various levels of technological literacy. Based on Margaryan et al. (2011), millennials do not as radically adapt to the new introduction of technology in the classroom as we feel. Consequently, the process of accepting these tools directly influences their behavioural intentions and the effectiveness of the learning process (Esteban-Millat et al. 2018). The learning process in schools is expected to train students to think critically. Teaching critical thinking is important because through critical thinking, students will be trained to observe conditions, raise questions, formulate hypotheses, make observations and collect data, then provide conclusions. Critical thinking also trains students to think logically and not accept things easily. According to the NEA National Education Association (2010: 8) the ability to think critically is important to help students develop their talents, train concentration and focus on problems and think analytically. In addition, critical thinking is defined as the process of conceptualizing, analyzing or synthesizing, evaluating and applying information to solve problems, expect action, seek answers to questions or reach conclusions. It consists of various aspects such as evaluating results, analyzing conclusions, considering decisions, analyzing problems, and so on.

The results of the identification of the objective conditions of learning physics in schools at this time indicate problems, including: (1) Many students can present a good level of memorization of the subject matter they receive, but in reality, do not understand it; (2) Most of the students were unable to connect what they learned with how this knowledge would be used/utilized; and (3) 
Students have difficulty understanding academic concepts as they are usually taught by using something abstract with the lecture method (Depdiknas, 2007). Whereas on the other hand, students need an understanding of concepts related to life activities in the community where they will live and work.

At this time teacher-centred learning is no longer suitable for the current generation so it needs to change to a more student-centred approach with a very diverse range of abilities. Based on the empirical findings that have been described previously, it is an indication that science learning at Kalam Christian Middle School Kudus Surakarta, which has been carried out so far, is a conventional activity that has an impact on the low critical thinking skills of students. So that this condition requires improvements in physics learning to realize effective physics learning, especially in junior high schools so that the process emphasizes more on products, processes and scientific attitudes. The Ministry of National Education launched the Information and Communication Technology Service Program to optimize learning media in the form of google.com facilities. The Minister of National Education hopes that these learning facilities can improve the quality of education and expand learning opportunities. Sudibjo Ari (2019). Google Classroom-based digital teaching materials are very appropriate for learning media to solve these student problems. The Google Classroom application has been used in various learning methods as support in learning activities and a form of support for current technological advances. The Google Classroom application is very easy to use in learning activities, even in March 2017 Google Classroom can be accessed by everyone via personal Google. The Google Classroom application can be downloaded for free on Android and iOS-based devices. As is well known, these two smartphone bases have become a basic necessity in the generation affected by COVID 19. Some of the features that teachers can use on Google Classroom are assignments, grading, communication, time-cost, archive courses, mobile applications and privacy (Maharani Nia, Ketut.SK, 2019).

Therefore, a teacher must have the skills to innovate and be ICT literate in the sense that a teacher must have the ability to master media, information and technology. Because according to Teknowijoyo Felixtian (2020), innovation in education is an absolute must for an educator in achieving educational success. $87 \%$ of educators in Spain admit that technology makes it ezsier and beneficial for them to find, or make teaching materials. An educator acts as an agent of change who helps motivate students with good and quality teaching materials. Goøgle Classroom makes it easy for an educator to preģare teaching materials, while students must have the ability to be flexible and adaptive, take initiative and be independent, be able to interact socially, be productive and be responsible.

\section{RESEARCH METHOD}

The method used in this research is descriptive analysis, namely by analyzing students' needs for the development of digital teaching materials based on google classroom using questionnaires and interviews. Besides, it also uses literature studies by looking for theoretical references from books and journals that are relevant to the cases or problems found. The theoretical references obtained utilizing literature study research serve as the basic foundation and the main tool for research practice in the field. The data collection method in this study is to search as much literature as possible, then study and compare the literature obtained so that it finds the data discussed in this research.

\section{RESULTAND DISCUSSION}

At this time the application of ideal and effective learning media is still not well implemented. From the results of preliminary observations through interviews with physics subject teachers at Kalam Kudus Christian Middle School, Surakarta, the school has implemented the 2013 curriculum but the learning method commonly used is the lecture method which is still teacher-centred, while the media commonly used are blackboards and powerpoint slides. Although some educators are using other media. This makes class conditions less comfortable and attractive to students because monotonous media makes students bored with these subjects. So that students become lazy and cannot accept learning well. Learning that cannot make students interested and active in teaching and learning activities cause a decrease in the level of enthusiasm of students in studying at school. Students become passive, not creative, and have no desire to know about their lessons. This has an impact on students' critical thinking skills which are still not optimal and so that the learning outcomes are also low, namely below the KKM score with a standard score of 78, the average physics learning at Kalam Kudus Christian Middle School in semester 1 of the 2019/2020 school year is:

Table 1. Average Value of Daily Physics Test

\begin{tabular}{|ccc}
\hline Class & Total Students & Average Value \\
\hline Regular A & 27 & 70.05 \\
\hline Regular B & 26 & 80.60 \\
\hline Regular C & 27 & 70.70
\end{tabular}


International Journal of English Literature and Social Sciences, 5(4)

Jul-Aug 2020 /Available online: https://ijels.com/

\begin{tabular}{llll}
\hline 4 & Regular D & 27 & 70.01 \\
\hline 5 & Regular E & 26 & 70.40 \\
\hline 6 & Regular F & 26 & 68.30
\end{tabular}

Source: Class VIII test scores of Kalam Kudus Christian

Middle School Surakarta in 2019

Based on table 1 above, it can be seen that the average test score acquisition for grade VIII students at Kalam Kudus Christian Middle School is still very far from KKM, namely the Regular A class with 27 students is still very low with an average score of 70.5 while the Regular B class with total students 26 with an average score of 80.60 , which is higher than the Regular class A. Then the Regular class C, D, E and F get a score below the maximum average, which is less than 75 compared to the regular class B. Thus, of the 6 regular classes, only one class fulfils the KKM score. The low student learning outcomes have an impact on the low level of critical thinking of students. This suggests that there are obstacles in the student learning process. Low learning outcomes can be caused because students are less active in the teaching and learning process. Small factors that can affect the low student learning outcomes are because the learning presented is still in an unattractive form, so that it seems difficult to understand students and does not really master the basic concepts contained in physics subject matter. This can hinder students' creativity in answering questions, which ultimately results in low student learning outcomes (Gumay, O. P. U., \&Framanta, A, 2019). Therefore, the learning resources used by the teacher must be adjusted to the characteristics and needs of students. The results of the analysis of the needs of Kalam Kudus Surakata Christian Middle School students are as follows.

Table 2. Analysis of Student Needs on the

Development of Teaching Materials Digital Based on Google Classroom

No Known Aspect

1. Do you agree if it is said that learning physics has been fun?

2. Is a Physics lesson one of its subjects preferred? not for playing. The advantages of Google Classroom are

3. Are the available textbooks sufficient (omesy to us $Q 0,3$ sque time, clo, 1 dobased, flexible, and free student per book)?

(Iftakhar, 2016). This is a consideration that Google Classroom is right for use in the world of learning. The use 4. Are the available textbooks available to of Google ${ }^{11}$ Classroom makes it easier for teachers to 
manage to learn and convey information precisely and accurately to students (Hardiyana, 2015). Through online learning, it is hoped that he can develop his abilities in a better direction. One of the abilities that are expected to develop properly is the ability to think critically in problem-solving (Unaifah, 2014).

The results of this study are supported by research conducted by Wicaksono \& Rachmadyanti (2017) which states that through the use of Google Classroom students become more comfortable and more active in constructing their knowledge. While the research conducted by Gunawan \& Sunarman (2018) in general, the success rate in the learning process using Google Classroom was $88 \%$ of the research design, problem-solving carried out by students was also following expected expectations, the problem-solving ability of students was increasing and the use of Google Classroom received a good response from students. The use of Google Classroom is effective for use in the learning process and can develop problem-solving in students. This view is also supported by Jakkaew and Hemrungrote (2017) who show that students' enthusiasm and motivation that comes from using the system affects their intention to use it. Again, the importance of performance expectations in determining intentions is already in the literature (Amadin et al. 2018; Abdul Wednesday et al. 2018).

Thus the development of Google Classroombased digital teaching materials is the basic foundation that everyone will build new forms of knowledge by combining the information that comes, then with what has been stored in memory, the results of previous learning. This is in line with the constructivist learning theory proposed by Burning (2004) which states that each form or builds a large part of what they learn and understand. Per the understanding of constructivism, google classroom-based digital teaching materials provide opportunities for students to construct their knowledge both through classroom learning and independent learning through elearning.

\section{CONCLUSION}

Based on the explanation above, it can be concluded that digital teaching materials using google classroom can be an alternative that can be used in learning as an effort to improve students' critical thinking skills. The results showed that almost all students wanted classroom-based digital teaching materials in learning activities, this can be seen from the acquisition of a questionnaire, which is $96.5 \%$ of students answered agree to apply classroom-based digital teaching materials. The development of digital teaching materials based on google classroom is the basic foundation that everyone will build new forms of knowledge by combining the information that comes, then with what has been stored in memory, and previous learning outcomes.

\section{REFERENCES}

[1] Amadin, F. I., Obienu, A. C., Osaseri, R. O., Omputer, D. E. O. F. C., Cience, S., Enin, U. N. O. F. B., et al. (2018). Main barriers and possible enablers of Google apps for education adoption among university staff members.

[2] Abdul Rabu, S. N. A., Hussin, H., \&Bervell, B. (2018). QR code utilization in a large classroom: higher education students' initial perceptions. Education and Information Technologies. https://doi.org/10.1007 /s10639-018-9779-2 https ://link.springer.com/journal/10639Nigerian Journal of Technology (NIJOTECH), 37(2), 432-439

[3] Gunawan, F. I., \& Sunarman, S. G.(2018). Pengembangan Kelas Virtual Dengan Google Classroom Dalam Keterampilan Pemecahan Masalah (Problem Solving) Topik Vektor Pada Siswa SMK Untuk Mendukung Pembelajaran. In Prosiding Seminar Nasional Pendidikan Matematika Etnomatnesia.

[4] Gumay, O. P. U., \&Framanta, A. (2019).Penerapan Model Pembelajaran Talking Stick pada Mata PelajaranFisikaSiswaKelas X SMA NegeriSukakarya. JurnalPerspektifPendidikan, 13(1), 65-72.

[5] Hardiyana, A. (2015) Implementasi Google Classroom sebagai Alternatifdalam Meningkatkan Mutu Pembelajaran di Sekolah. Karya Tulis Ilmiah, Cirebon : SMA Negeri 1 Losari

[6] Insani, M.D. (2016). Studi Pendahuluan Identifikasi Kesulitan Dalam Pembelajaran Pada Guru Ipa SMP Se-kota Malang. Jurnal Pendidikan Biologi Volume 7

[7] Iftakhar, S. (2016). Google Classroom : What Works and How ?. Jurnal of Education and Social Science, 2 (3) , 12-18

[8] Jakkaew, P., \& Hemrungrote, S. (2017). The use of UTAUT2 model for understanding student perceptions using Google classroom: A case study of introduction to information technology course. 2017 International Conference on Digital Arts, Media and Technology (ICDAMT), 205-209. https://doi. org/10.1109/ICDAMT.2017.7904962

[9] Kumar Jeya Amantha \& Brandford Bervell (2019).Google Classroom for mobile learning in higher education:Modelling the initial perceptions of students.Jurnal Education and Information Technologies. https://doi.org/10.1007/s10639-018-09858-Z

[10] Margaryan, A., Littlejohn, A., \& Vojt, G. (2011). Are digital natives a myth or reality? University students' use of digital technologies. Computers in Education,56(2),429-440. https://doi.org/10.1016/j.compedu.2010.09.004

[11] Maharani Nia, Ketut.S.K, 2019. Penggunaan google classroom sebagaipengembangankelas virtual dalamketerampilanpemecahanmasalahtopikkinematikapada mahasiswajurusansistem computer. Journal of Science Education, $\quad$ Vol.3 (3), 167-1173. 
https://ejournal.unib.ac.id/index.php/pendipa

[12] Subdijo Ari. (2019). Penggunaan media pembelajaran ipa berbasis google Classroom pada materi alat optik untuk Meningkatkan respons motivasi dan hasil belajar Siswa di smp negeri 4 surabaya. Jurnal Education and development. Vol.7 No.3 2019.

[13] Teknowijoyo Felixtian (2020).Media Pembelajaran Berbasis Google Edukasi untuk Meningkatkan Hasil Belajar Peserta Didik pada Pelajaran Fisika di SMP. Jurnal of Curriculum Indonesia Vol.3 2020. http://hipkinjateng.org/jurnal/index.php/jci

[14] Unaifah, F., Suprapto, N. (2014). ProfilKemampuanPemecahanMasalahdanHasilBelajarSiswa padaMateriElastisitasditinjaudari Gaya Belajar (Learning Style). Jurnal Inovasi Pendidikan Fisika, 3(2), 27-32Viridi, S.,

[15] Wicaksono, V. D., \& Rachmadyanti, P.(2017). Pembelajaran Blended Learning Melalui Google Classroom Di Sekolah Dasar. Seminar Nasional Pendidikan PGSD UMS \& HDPGSDI Wilayah Jawa (2017) 